MAR K E D W A R S

\title{
CATHOLICITY
}

R

\section{AND HERESY IN THE EARLY CHURCH}

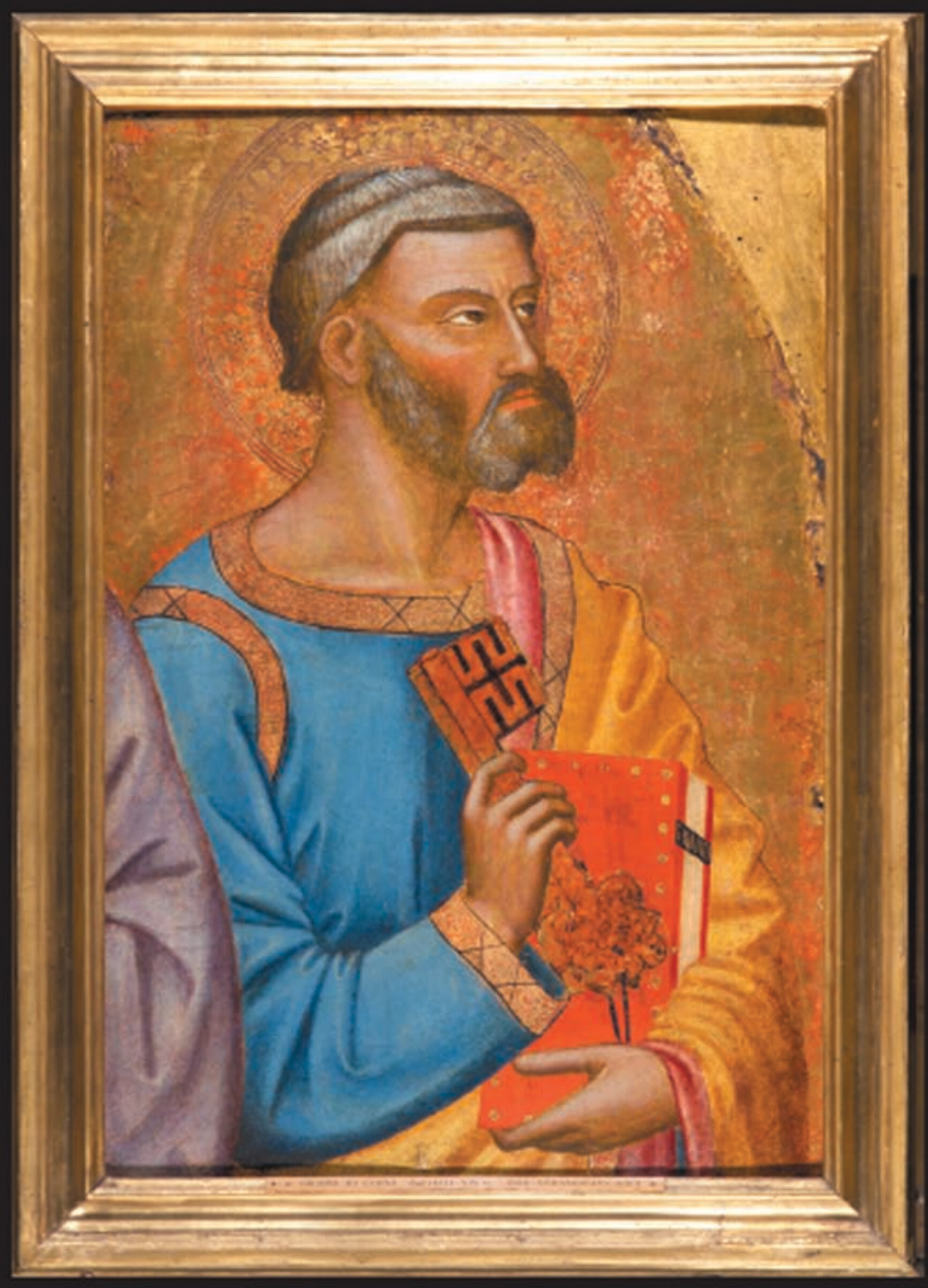




\section{CATHOLICITY AND HERESY IN THE EARLY CHURCH}

While it has often been recognised that the development of Christian orthodoxy was stimulated by the speculations of those who are now called heretics, it is still widely assumed that their contribution was merely catalytic, that they called forth the exposition of what the main church already believed but had not yet been required to formulate.

This book maintains that scholars have underrated the constructive role of these "heretical" speculations in the evolution of dogma, showing that salient elements in the doctrines of the fall, the Trinity and the union of God and man in Christ derive from teachings that were initially rejected by the main church. Mark Edwards also reveals how authors who epitomised orthodoxy in their own day sometimes favoured teachings which were later considered heterodox, and that their doctrines underwent radical revision before they became a fixed element of orthodoxy.

The first half of the volume discusses the role of Gnostic theologians in the formation of catholic thought; the second half will offer an unfashionable view of the controversies which gave rise to the councils of Nicaea, Ephesus and Chalcedon. Many of the theories advanced here have not been broached elsewhere, and no synthesis on this scale had been attempted by other scholars. While this book proposes a revision in the scholarly perception of early Christendom, it also demonstrates the essential unity of the tradition. 
For Mark Allen 


\section{Catholicity and Heresy in the Early Church}

MARK EDWARDS

Christ Church, Oxford, UK

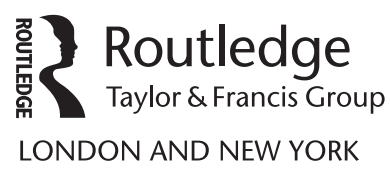


First published 2009 by Ashgate Publishing Limited

2 Park Square, Milton Park, Abingdon, Oxfordshire OX14 4RN

52 Vanderbilt Avenue, New York, NY 10017

Routledge is an imprint of the Taylor \& Francis Group, an informa business

First issued in paperback 2018

Copyright (C) Mark Edwards 2009

Mark Edwards has asserted his right under the Copyright, Designs and Patents Act, 1988, to be identified as the author of this work.

All rights reserved. No part of this book may be reprinted or reproduced or utilised in any form or by any electronic, mechanical, or other means, now known or hereafter invented, including photocopying and recording, or in any information storage or retrieval system, without permission in writing from the publishers.

Notice:

Product or corporate names may be trademarks or registered trademarks, and are used only for identification and explanation without intent to infringe.

\section{British Library Cataloguing in Publication Data}

Edwards, M. J. (Mark J.)

Catholicity and heresy in the early Church. 1. Church history-Primitive and early church, ca. 30-600. 2. Church-Catholicity. 3. Theology, Doctrinal-History-Early church, ca. 30-600. 4. Heresy-History. 5. Gnosticism-History.

I. Title

$273.1-\mathrm{dc} 22$

\section{Library of Congress Cataloging-in-Publication Data}

Edwards, M. J. (Mark J.)

Catholicity and heresy in the early church / Mark Edwards.

p. cm.

Includes bibliographical references.

ISBN 978-0-7546-6291-4 (hardcover : alk. paper) — ISBN 978-0-7546-6297-6 (pbk. : alk. paper) 1. Church history-Primitive and early church, ca. 30-600. 2. ChurchCatholicity. 3. Theology, Doctrinal-History-Early church, ca. 30-600. 4. HeresyHistory. 5. Gnosticism-History. I. Title.

BR162.3.E39 2009

273 '.1-dc22

2009009320

ISBN 978-0-7546-6291-4 (hbk)

ISBN 978-0-7546-6297-6 (pbk) 


\section{Contents}

Introduction $\quad 1$

1 The Gnostic Beginnings of Orthodoxy 11

2 The Catholicity of Irenaeus $\quad 35$

3 The Foundations of Catholic Teaching in the Third Century 57

$\begin{array}{lll}4 & \text { Origen and Orthodoxy } & 79\end{array}$

$\begin{array}{lll}5 & \text { The Nicene Council and its Aftermath } & 105\end{array}$

$6 \quad$ Apollinarius and the Chalcedonian Definition 137

$\begin{array}{lr}\text { Epilogue } & 173\end{array}$

$\begin{array}{lr}\text { Bibliography } & 177\end{array}$

$\begin{array}{lr}\text { Index } & 195\end{array}$ 


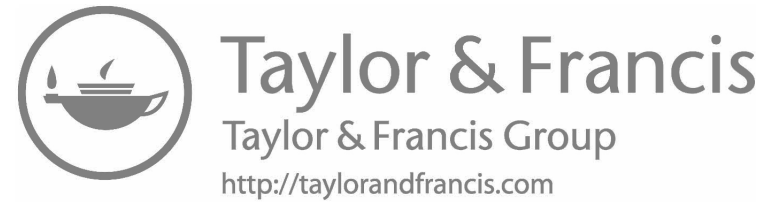




\section{Introduction}

In academic circles, it is nowadays unnecessary to prove that the teachings of the Christian churches have a history, that the doctrines of the Trinity, of the union of two natures in the incarnate Christ, of the fall and the atonement, of the real presence in the sacrament and of the church itself as the body of Christ were not communicated as a system to the apostles, even by the risen Jesus. Again it is unnecessary to demonstrate that the growth is in part the result of the incubation of the gospel in a particular environment, ${ }^{1}$ and not merely the unfolding of an embryonic pattern according to some instinctive or organic principle. Indeed the prevailing notion seems to be that there was at first no line in the development of doctrine, that for three centuries a plethora of antipathetic tenets and speculations fought to maintain themselves until at last the world proved hospitable only to one variety. We might say that a teleological theory of evolution has been succeeded by a Darwinian one, except that the discriminating forces in the evolution of Christian doctrine are generally supposed to have been adventitious rather than endemic. In recent years the narrative has been modified to suggest that the multiplication of 'Christianities' was accelerated rather than arrested by the Council of Nicaea in 325 , which is often supposed to have inaugurated the process of unnatural selection which has left us with orthodoxy. Yet since the majority of these experiments too are assumed to have been abortive, the prevailing story is still one that recounts the destruction of a superfluous harvest, a constrained or guided dwindling from the many to the one.

It is not my object in the present study to deny that the norms of Christian thought, as these have been understood by many since the mid-fifth century, are a product of disparate forces, most (to a human eye) contingent, some extrinsic and none perhaps entirely consistent in its operation. I do wish to suggest that the concept of orthodoxy is part of the deposit, that so long as a gospel has been proclaimed it has always been accompanied by harangues against false professors. At the same time, I contend that, while there was evidently some difference of belief and much diversity in the expression of belief, there was no unregulated ferment of opinion such as is posited by those who speak of different and competing Christianities. The episkopoi or overseers, ${ }^{2}$ who were formidable guardians of a norm which they believed to be that of Paul and the evangelists, were intolerant of locutions or conceits that were not of apostolic provenance; consequently they saw only a polar antitype to the gospel in other systems which, more liberally construed, would

1 For temperate appraisals of the influence of philosophy see Studer (1998), 170-94; Ramelli (2007), 959-1092.

2 See Philippians 1.1 and Küng (1968), 399-400. 
have been discovered to be largely coextensive with their own. But systems which are mutually reducible are unlikely to remain mutually immiscible. The Gnostics and their dark twins the monarchians answered questions which could not fail to be questions for the episcopate: their premises were frequently alluring, their difficulties unavoidable. It is not surprising, then, that while episcopal theology owed its shape to the exigencies of polemic, it derived its substance from a common patrimony - that Olympus, in short, defended itself with thunderbolts forged by Titans. In Africa and Egypt minor clerics or lay satellites of the episcopate made free use of foreign arsenals, and in consequence were more vulnerable than the bishops themselves to the imputation of heresy in their own time. Yet, deviants and schismatics, though they remain to this day in the eyes of magisterium, are also numbered informally among the church fathers because it was their husbandry that assisted the germination of a new orthodoxy after the Nicene Council of 325. It was fear of the errors that seemed to be still implicit in this inheritance that led others to propose alternatives to the Nicene formula. In many cases, the only result of strife between sees was a hardening of contradictory dogmas; the peace that was concluded at last, however, represented not the ascendancy of a single school, but a confluence of several, including some that, to all appearance, had been abandoned or exploded before the council of 325. It was not so much by attrition as by ingestion that a creed matured which deserved the appellation 'catholic'.

Of the seven tests proposed by J.H. Newman as 'notes' or indices of true development rather than corruption, ${ }^{3}$ he himself attached most consequence to preservation of type and continuity of principle. Neither is satisfactory, since there is no early Christian movement which is demonstrably unfaithful to the type laid down by Jesus, and there is no hermeneutic or philosophic principle which yielded only heterodox logomachies without enlarging the catholic proclamation. The test which Newman should have accentuated as a 'note' of catholicity is the power of assimilation, which extends, as I shall hope to prove in the present book, to the assimilation of teachings which to Newman himself seemed aberrant and unworthy of the name 'Christian'. In this introduction, I shall first explain what I understand by 'orthodoxy' in the early church, and then give a brief synopsis of the evidence that I shall adduce to illustrate the workings of the ecclesiastical loom.

\section{The Keys of Orthodoxy}

There is scarcely any book of our New Testament which does not contain an invective against false teaching. Even in canonical writings twentieth-century scholars have professed to discover tenets that are mutually inimical, and it has been inferred that the preaching of Jesus, together with his death, gave rise to a constellation of distinct communities, each proclaiming a different gospel. On this view it is possible to contrast the liberal efflorescence of the earliest years with

\footnotetext{
3 Newman (1845).
} 
the tyrannical pruning of the credal age. It must be observed, however, that not every scholar believes that we have inherited such a heterogeneous canon, and that wherever an open difference of belief is recorded in our New Testament, one belief is deemed to be erroneous. In many cases the author admits that the aberrant view has been defended with eloquence and has proved seductive to many; in no case does he admit any test of orthodoxy but his own conviction. While the term 'orthodoxy' does not occur, we meet its antonym hairesis in Paul's letter to the Galatians, perhaps the earliest document in the canon; here and everywhere in Christian literature thereafter, it signifies not the mere choice of a sect or school, but a damnable perversion of the gospel. To require circumcision of neophytes is to spurn Christ's general amnesty to sinners, to maintain that the resurrection is come already is to make shipwreck of one's faith, and to deny that the Son of God came in the flesh as Jesus is to be antichrist. All this is established more by combination than by argument; with the passing of the last apostle, however, those who had hitherto been condemned might urge that no-one now had the power to impose a yoke upon belief.

Although Paul speaks of overseers (episkopoi) and servitors (diakonoi) in the first verse of his epistle to the Philippians, it is only in the letters that are addressed in his name to Timothy and Titus that we find precepts for the ordination of an official ministry. ${ }^{4}$ Because these texts are commonly held to attest a threefold ministry of episkopoi, presbuteroi and diakonoi, it is frequently asserted that they cannot come from the hand of Paul himself, but betoken a subsequent development which could be established only by imposture. This reasoning, however, would appear to be either circular or irrelevant to modern deliberations on the structure of the church. In the present state of our knowledge, to deny that Paul himself could have been acquainted with three orders of Christian ministry is simply to beg the question, unless it is to be taken as an axiom, that such a development cannot have taken place within a single generation. But if this is an axiom, it is so whether God or man devised the three fold ministry; no proof that the God's intending it can therefore be derived from the date of the pastoral letters, or from the erroneous attribution. The puritan who urges that the Church should preach and practice only what is enjoined in the earliest texts must hold that it was possible for all the lasting mandates of the church to be issued in the first generation; in that case, he may not have any safe ground for denying the authorship of these letters to Paul.

The first author who unambiguously speaks of the episcopate, the presbyterate and the diaconate as three orders within the same churches is the happy pilgrim of death who styles himself Ignatius, Bishop of Syria (Romans 2); posterity has assumed that his see was Antioch, since he alludes to it as his home. His martyrdom is dated to about 110 A.D., and Walter Bauer, who argues that heretical teaching was everywhere the precursor of orthodoxy in the first century after Christ is therefore

4 For the juxtaposition of the episcopate and presbyterate, which are not yet clearly distinguished see Titus 1.5-8. For the ordination of Titus as bishop see Titus 1.7; for Timothy as presbyter see 1 Timothey 4.14 and 2 Timothey 1.6. 
bound to maintain that Ignatius is speaking only for a faction, and that the majority of Christians in the Asiatic towns to which he wrote denied the authority of the bishop. ${ }^{5}$ Nowhere, however, do the letters testify to any defiance of episcopacy as an institution; his opponents, who 'acknowledge the bishop in name and yet do everything without him' seem to differ only in contesting the qualifications of a particular incumbent and in claiming the right to gather for worship and teaching in his absence. Ignatius, unacquainted as he is with the constitution of the Roman see, does not refer to the bishop in his letter to that congregation, which is written in a less magisterial character than his letters to the Asiatic churches; but Irenaeus, writing about 180 , not only supplies a list of Roman presidents reaching back to Peter and Paul, ${ }^{6}$ but assumes in his letter of counsel to Bishop Victor of Rome that the latter is the sole arbiter of practice in the capital. ${ }^{7} \mathrm{He}$ cites the predecessors of Victor, not to show that Rome had ever been without a monarchical episcopate, but to illustrate the forbearance which these worthies had observed in their exercise of the powers that Victor proposed to wield. When, a generation later, Callistus was pronounced unworthy of the monarchical office by a bilious prelate attached to his communion, the latter could not deny that Callistus was the sole tenant of the Roman see. Of episcopal successions in other provinces we generally have no evidence but the sparse lists in Eusebius; but in the cases where some primary source augments our knowledge - for example, the letter in which the Antiochene bishop Serapion justifies his suppression of the Gospel of Peter - the bishop entertains no doubt of his role as principal officer of the church, with power to license or proscribe (Eusebius, Church History 6.12).

Both Victor and Serapion announced their local rulings to other bishops, and communication by official letters, or formatae, was considered an ancient practice in the fourth century. Irenaeus speaks of a rule of faith, which is not peculiar to any one see, but a universal adamant which shivers falsehood in Rome as in Lyons, in Antioch as in Alexandria. He does not prove what he asserts - that if we reckon up the incumbents of all the major sees from the time of the apostles, we shall find that all preach the same doctrine - but Tertullian, writing in Carthage and in Latin thirty years after him, also invokes a rule of faith, which for him as for Irenaeus excludes Basilideans, Valentinians, Marcionites and Gnostics. The same four groups are denounced on numerous occasions by Tertullian's younger contemporary Origen; the latter, in the proem to his early work 'On First Principles', sets out what he believes to have been the teaching of the apostles in a series of articles, all of which Irenaeus and Tertullian would have endorsed without misgiving. Clement makes a fourth, and Hippolytus too condemns the same parties that the others

5 Bauer (1970), 60-80.

6 For Peter and Paul in Rome see 1 Clement 5; Ignatius, Romans 4.3; Irenaeus, Against Heresies 3.2.

7 See Against Heresies 3.2 with Molland (1950); Eusebius, Church History 5.24 with the commentary of Richard (1965). 
deem heretical. Among writers who acknowledge the episcopate we find, if not unanimity of belief, at least consensus regarding the boundaries of the church.

These authors also recognise the same canon of Christian scriptures, which had come to be called the New Testament by the beginning of the third century. According to Irenaeus, the true church knows no evangelists but Matthew, Mark Luke and John. The others signify by their quotations that they agree with him, and even Clement, who draws occasionally on other gospels, did not venture in his Hypotyposes to comment on them as he comments on the four that Irenaeus deems inspired. The fourteen texts ascribed to Paul included Hebrews, Titus and the two epistles to Timothy; Origen, who is said to have challenged the authorship of Hebrews, seldom fails in quoting it to advertise his belief in its authority by describing it as the work of the Apostle. In the fourth century, Hebrews and the Apocalypse of John were reckoned among the dubious writings, but the canonicity of the latter was seldom doubted up to the mid-third century. The five great theologians who flourished between 180 and 250 all concur in treating scripture as the sole foundation for argument against heresy; at the same time it is the church (as they understand this term) that furnishes the norms of interpretation, and even Origen never has the hardihood to elicit a sense from the text that contravenes the rule of faith.

It cannot be maintained, then, that before the Nicene Council of 325 there was no magisterial body which purported to define what could be believed and to wield the keys that Christ bestowed on the apostles. It cannot even be argued that the teaching of the episcopate displayed more uniformity after the Council than before it, for in fact it was only after Nicaea that the episcopate crystallized into maledictory factions, each pretending to have the one formula that would encompass all the necessary truths without giving a handle to false speculations. We do of course hear of discord among the bishops before Nicaea, but the feud between Victor of Rome and the Asiatics would appear to have subsided quickly enough (if we may judge by the silence of authors after Irenaeus), and even Hippolytus stops short of pronouncing Callistus a heretic or attempting to dethrone him. When the tenancy of a particular see was contested - as at Rome and Carthage under imperial persecution in the $250 \mathrm{~s}$ - the charge against the incumbent was that his discipline was too lax, not that his doctrine was unsound. It seems that a bishop might be called to account for his doctrines by another bishop, as, for example, when Dionysius of Alexandria explained to Dionysius of Rome his reluctance to affirm a common essence in the Godhead; but in this case it would seem that the question never became a quarrel. ${ }^{8}$ Only one bishop whose tenure had been unopposed at the outset was subsequently driven from his see by the suffrage of his fellow-bishops: Paul of Samosata, bishop of Antioch, was too powerful to be ousted without the assistance of the emperor, and his teaching that the Saviour was no more than a man inspired by God was cherished by a party which continued to exercise legislators and councils for centuries afterwards. Nevertheless his

8 See Athanasius, On the Opinion of Dionysius, with Abramowski (1992a). 
departure does not seem to have given rise to any schism in the episcopate, and the story of his dethronement is narrated by Eusebius as an example of the Church's power to act with a common will against the incorrigible (Church History 7.30). Before Nicaea perfect unanimity of doctrine among the bishops was an ideal that had not yet been exposed as a mirage.

Of course there was more dispute when there were more heads to differ and more that demanded public resolution. After Constantine's victory in the east, the formation of parties was encouraged by the multiplication of bishoprics, the suppression of legal impediments to intercourse between Christians and the unprecedented vigilance which was applied to the conscience even of minor prelates. There can be no doubt that the formulations of the conciliar age combine a menacing severity with a superficial clarity of diction that the older rule of faith had exhibited only when it was tempered to the hand of a particular controversialist. Yet the change, so far as change occurred, proved lasting only because it was gradual, undeclared and at first insensible. The Nicene definition of 325 procured twenty years of peace because it defined so little. The poison of Gnostic teaching was assumed to be so inert that one could revive the word homoousios with impunity; the Monarchians were tacitly admonished by the juxtaposition of clauses referring severally to Father, Son and Spirit; if individual prelates choose to quarrel about the eternity of the Son or the legitimacy of styling him a creature, the church as a whole remained incombustible. Once a general desire arose to dispel the ambiguities of the creed, this truce was irreparably broken, and no formula that was imposed upon the church between 350 and 361 survived the meeting that proclaimed it. ${ }^{9}$ After an unruly moratorium of twenty years, it was partly the fatigue of the disputants, partly the statesmanship of the great Theodosius, and above all no doubt the passing of the principal agitators, that enabled the church to coalesce around an amplified version of the creed of 325.

Systematicians frequently imagine that after 381 there remained but one great schism to be healed, and that the salve was applied in 451 by the Chalcedonian formula which affirms two natures in Christ. In fact, as we shall see in the final chapter, nothing was settled at Chalcedon which had not already been settled in 433 at the Oecumenical Council of Ephesus. The odium which this council had excited in certain quarters of the east was not appeased in 451, though on the same occasion turbulent partisans of Cyril, the victor at Ephesus, suffered a reproof which led within years to a secession. The churchmen whom these malcontents had driven from their sees were temporarily restored, but some were found at a posthumous assize to have been heretics after all. The Council of Constantinople in 553 which vindicated Cyril against his enemies and Chalcedon against its critics was accepted by the Papacy under duress ${ }^{10}$ and in defiance of western opinion. During the previous century the best intellects of the east had been intent upon

9 See Athanasius, On Synods; Barnes (1993); Ayres (2004).

10 The role of coercion in previous councils seems to me to have been exaggerated by Macmullen (2006) and De Ste-Croix (2006). 
the defence, the supersession or the rebuttal of the Chalcedonian formulae; the cunning elucidations which were ratified at last in the Byzantine church were seldom read by the western clergy, and have never been reduced to a creed for the laity in either half of Christendom. The un-reconciled Nestorians of Syria and the discontented Cyrillines of Egypt ceased to molest the Emperor's counsels only when they had been irrevocably torn from his dominion by the Arabs. In the west his writ was dead without the assistance of the Pope, and the Pope in turn could wield no power except by making a tool of princes who desired him as a talisman against their own rivals or against Byzantium.

We must remember that laws in the ancient world were not published with the celerity or the ubiquity that a modern legislator takes for granted, and that, outside a few great cities, they could not be enforced with universal rigour. Even before the extinction of Roman government in the west, the decrees of an oecumenical council laid no burden on the incumbent of a minor see or even the dissident patriarch who commanded the seamless loyalty of his province. Those who had not been present at a council were unlikely to see a copy of its rulings; the majority of the people, who (in common, no doubt, with many of their clergy) were illiterate, were allowed to believe or disbelieve in silence. If by orthodoxy we mean an opinion which was held without demur by the entire body of the faithful, there was no orthodoxy - and hence, if you will, no church - from the time of Jesus; if we mean the expressed consensus of those prelates who were summoned to general councils, it is easier to discover orthodoxy before Nicaea than in any subsequent period of ecclesiastical history, from the fourth century to our own.

\section{Plan of the Work}

Orthodoxy is thus whatever is taught in any epoch by the majority of bishops, and to be catholic is to concur with this majority. It does not, however, follow that we ought to begin, as conventional genealogies of doctrine do, with the first acknowledged representatives of episcopal teaching, for that would be to forget the provisional character of the norm in each generation and its capacity to grow by the assimilation of tenets that had not been fathered by the episcopate. In any case, it has seldom been found profitable to look for intimations of a future orthodoxy in the writings of the apostolic fathers or the apologists, as the latter wrote primarily to deflect false accusations while the former touch on doctrine only so far as is necessary to arm the faithful against temptation or distress. The pioneers of Christian speculation, as I shall argue in the first chapter, were Basilides, Valentinus and Marcion - authors who are often relegated to the hinterland of ecclesiastical history because they appear in the guise of heretics even in our earliest testimonies. Whether the myths to which they appealed were of pagan or Christian provenance we need not determine here, since when a Gnostic is named the teachings attributed to him purport invariably to be readings of or supplements to the gospel. We cannot, on the other had, point to a catholic antecedent for their 
reflections on the loss of the heavenly archetype in man, the eternal sonship of the Redeemer and the omnipresent ministry of the Cross. In Chapter 1 I shall trace the incipient lines of catholic dogma in these innovators and their anonymous mentors; in Chapter 2 I shall argue that their principal critic, Bishop Irenaeus of Lyons, could not pursue them except by shadowing their manoeuvres, and that where he fails to anticipate the consensus of later times, it is because he has been guided by their premises or deterred by their example. Like many a notable piece of Christian music, his theology is the orchestration of an existing score.

In Chapter 3 I shall argue that the Alexandrian catholics Clement and Origen both took booty from their Valentinian neighbours, building systems which were partially homologous with those that their faith required them to eschew. This was the heresy of heresies for all Alexandrian catholics of this Monarchian confusion of Father and Son, but in this chapter I shall canvass the possibility that the dispute between Trinitarians and Monarchians was inflamed, if not occasioned, by the misunderstanding of an ambiguous watchword. No spokesman of the episcopal consensus could deny that Jesus of Nazareth was one person (hen prosopon) with the incarnate Word, whom some Trinitarians styled the second hypostasis and others the second persona or prosôpon of the Godhead. The same Formula that was anathematized when it seemed to reduce the Son to an appurtenance of the father became a touchstone of orthodoxy when it signified that there is one Sin and not two. But in the third century those who detached themselves from the Monarchians were inevitably suspected of making terms with the opposite heresy, and we shall find in Chapter 4 that even Origen's apologists, within sixty years of his death, were so afraid of following him into the Valentinian camp that they conspired with his detractors to intercept the approach to Nicene orthodoxy.

The Nicene settlement, as will become apparent in Chapter 5, did not result in a formal vindication of Origen, but in persecution from another quarter. Nevertheless he must be counted among the progenitors of the Trinitarian doctrine that is now considered orthodox. So too perhaps should the Gnostics, some of whose speculations can be shown to have been adapted for catholic use against the Arians. One extant tract suggests that a Gnostic group was at war with those whom the Nicene party stigmatized as Anomaeans; the latter kept half their arsenal for the so-called homoousians, who, in contrast to the Nicenes with their Gnosticizing fables of emanation, preached two equipollent gods. The homoousian legacy to the Church is thus no compromise (as is commonly alleged), but an augmentation of Nicene teaching on the Son's divinity. In Chapter 6 I hope to refute another theory of accommodation. When the Chalcedonian Council of 451 affirmed the coexistence of two natures in the Saviour, it corrected a false interpretation of Cyril of Alexandria, but did not redeem any portion of the teaching of Nestorius, whose condemnation Cyril had secured some twenty years earlier at the third oecumenical council. On the contrary, in predicating a real birth and real death of the Nazarene who was also God, it ensured that Cyril's teaching on the passibility of the incarnate Word would not be invidiously conflated, as Nestorius and his allies wished, with the heresies ascribed to Apollinarius. The salutation of Mary as 
Theotokos or Mother of God, the assertion that it was God who died on the Cross and even the formal attribution of two natures to the Son were all Apollinarian tenets to Nestorius, and the canonisation of Cyril's letters in 451 entailed a tacit rehabilitation of hitherto controverted teachings. On the other hand, Apollinarius' substitution of the Word for the human soul in Christ remained as unpalatable to the Chalcedonian fathers as to Cyril; neither would appear to have been aware that by insisting on the presence of this element, they were bringing a suit on Origen's behalf against the catholics who had first put him in the dock.

The term 'catholic' (from the Greek kath' holou) seems to have been intended at first to comprehend the whole body of the elect, ${ }^{11}$ as opposed to the local congregation. As early as the third century, this body was so divided that the catholic church was merely one of a number of communions - the sole communion, as its champions boasted, which was never called by another name even when it was persecuted or impugned. ${ }^{12}$ One proof of its catholicity, they urged, was that, in contrast to its rivals, its was represented in every proportion of the inhabited world; another was its willingness to tolerate the tares alongside the wheat, and to offer terms of readmission to those whom others put beyond the reach of mercy. The present study suggests that it was catholic in a sense that it might have preferred to disown, since, notwithstanding its fanciful claim to preserve the one truth handed down to the heirs of the apostles, it was the church that lent its countenance most readily to the mingling of the old and the new, as liberal in receiving the chastened form of an idea that it had once declared unlawful as in taking back the excommunicate who abjured his sin.

11 Zisioulas (1988), 144 denies that it has this meaning in the proem to the Martyrdom of Polycarp (Lightfoot, 1885-1890, vol. 5, 948) on the grounds that it would be pleonasm to speak of a universal church 'throughout the world'. But if the term 'universal' indicates merely that the whole church is spoken of, it says nothing about the dimensions of that church.

12 Augustine, On True Religion 7.12; Martyrdom of Pionius 9.6 at Knöpf (1901), 65. 